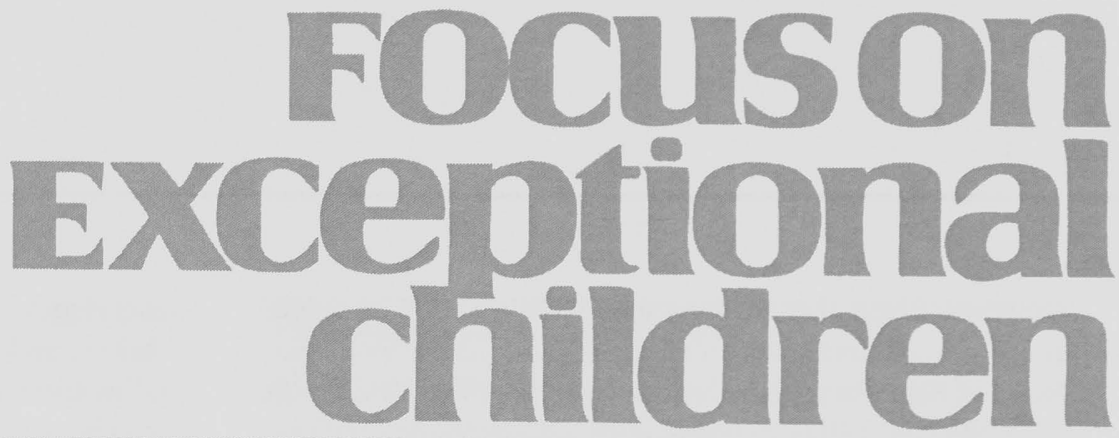

\title{
Bullying and Students with Disabilities: The Untold Narrative
}

\author{
Chad A. Rose, Susan M. Swearer, and Dorothy L. Espelage
}

The documentary Bully was released nationwide in theaters in March 2012. Originally titled The Bully Project, the filmmakers followed five families whose lives had been turned upside down by bullying. Two of the families in the movie lost their sons, Tyler and Ty, to suicide, and three of the youth in the movie, Alex, Kelby, and Ja'Meya, were bullied in school and on the school bus. The movie shows the devastating consequences of bullying and the depressingly poor response on the part of adults. What the movie does not address is the mental health history of one of the boys, who commits suicide, as well as the developmental disabilities affecting another boy in the movie, who was born prematurely (Bazelon, 2012). Understandably, this is a difficult narrative. The filmmakers did not want to delve into the complexity of mental health issues and bullying for fear of creating a story line that those who are bullied are obvious victims. However, by not addressing the issues of ADHD, bipolar disorder, Asperger syndrome, and developmental disabilities, an important narrative was missed. Bullying is a complex phenomenon, and both mental health and physical health difficulties play into involvement in bullying. While there is no narrative that those who are bullied somehow deserve such egregious treatment, we shirk our professional responsibilities if we do not shed light on the compelling evidence that youth with disabilities are at great risk for involvement in bullying - both for bullying others and for being bullied (AbilityPath.org, 2011; Rose, Monda-Amaya, \& Espelage, 2011). The purpose of this article is to review the research on bullying and students with disabilities and to propose an inclusive narrative: when differences are celebrated rather than used as fuel for maltreatment, a world will be created where bullying is not tolerated. This will be a better world for everyone.

\section{THE STATE OF RESEARCH ON BULLYING, VICTIMIZATION, AND STUDENTS IN SPECIAL EDUCATION}

Research on bullying and victimization by and toward students with disabilities is in its relative infancy in the United States. International research on bullying and students with disabilities started in the early 1990s. One seminal study conducted in the United

Dr. Rose is assistant professor of special education in the Department of Language, Literacy and Special Populations at Sam Houston State University, Dr. Swearer is professor of school psychology in the Department of Educational Psychology at the University of Nebraska-Lincoln, and Dr. Espelage is professor of child development in the Department of Educational Psychology at the University of Illinois at Urbana-Champaign. 
Kingdom found that students who were enrolled in special education curricula were victimized and perpetrated more bullying than their general education peers (Whitney, Smith, \& Thompson, 1994). Fewer studies have examined bullying experiences in student populations inclusive of students in special education in the United States. However, a recent study by Rose, Espelage, and Monda-Amaya (2009) examined rates of bullying perpetration and victimization among middle school $(n=7,331)$ and high school students $(n=$ 14,315 ) enrolled in general education and special education programs. As hypothesized, students in special education programs reported greater rates of bullying perpetration and victimization than students in general education without disabilities. Students who were in self-contained classrooms reported more perpetration and victimization than students with and without disabilities in inclusive settings. Swearer and colleagues studied 816 students in grades 5 through 9 who were in general and special education and compared the groups on involvement in bullying and prosocial behaviors. They found that the 130 students (ages 9-16) who were

\section{Focuson
Exceptional
children}

ISSN $0015-511 \mathrm{X}$ FOCUS ON EXCEPTIONAL CHILDREN (USPS 203-360) is published monthly except June, July, and August as a service to teachers, special educators, curriculum specialists, administrators, and those concerned with the special education of exceptional children. This publication is annotated and indexed by the ERIC Clearinghouse on Handicapped and Gifted Children for publication in the monthly Current Index to Journals in Education (CIJE) and the quarterly index, Exceptional Children Education Resources (ECER). The full text of Focus on Exceptional Children is also available in the electronic versions of the Education Index. It is also available in microfilm from Serials Acquisitions, National Archive Publishing Company, P.O. Box 998, Ann Arbor, MI 48106-0998. Subscription rates: individual, \$50 per year; institutions, \$68 per year. Copyright (C) 2012, Love Publishing Company. All rights reserved. Reproduction in whole or part without written permission is prohibited. Printed in the United States of America. Periodical postage is paid at Denver, Colorado. POSTMASTER: Send address changes to:

Love Publishing Company

Executive and Editorial Office P.O. Box 22353

Denver, Colorado 80222

Telephone (303) 221-7333

\section{CONSULTING EDITORS}

Steve Graham Vanderbilt University
Ron Nelson

University of Nebraska-Lincoln

Eva Horn

University of Kansas

Carrie E. Watterson

Senior Editor
Stanley F. Love

Publisher receiving special education services were 1.43 times more likely to self-identify as bully-victims (i.e., those who both bully others and who are bullied) than their general education classmates (Swearer, Wang, Maag, Siebecker, \& Frerichs, 2012). Involvement in bullying affects both students in regular and special education; however, students in special education may be at particular risk.

Indeed, research suggests that youth with learning and developmental disabilities are at risk of peer victimization (Baumeister, Storch, \& Geffken, 2008; Humphrey, Storch, \& Geffken, 2007; Marini, Fairbairn, \& Zuber, 2001; Sánchez, \& Cerezo, 2010; Saylor \& Leach, 2009; Thompson, Whitney, \& Smith, 1994). However, it is evident that rates of victimization vary by disability type and context (see review by Rose, Monda-Amaya, \& Espelage, 2011). More specifically, students with high incidence disabilities often experience less victimization than students with more significant cognitive or physical disabilities. Additionally, students in special classes or segregated schools appear to be victimized more often than students with and without disabilities in inclusive settings. Rose, Monda-Amaya, and Espelage, (2011) postulated that children and adolescents with disabilities are victimized in school because they may be passive in relating to their peers. In contrast, Kaukiainen and colleagues (2002) reported that, while learning disabilities were not related to victimization rates, they were related to involvement in perpetrating bullying. These researchers argued that children and adolescents with learning disorders have difficulties interpreting verbal and nonverbal communication and have poor social skills, which might contribute to them behaving aggressively toward others.

\section{DEFINITIONAL QUAGMIRE}

One issue plaguing the fields of special education and bullying/victimization is the myriad of definitions for disability status (i.e., differences between IDEIA and the DSM$I V$ classification system) and involvement in bullying (i.e., bully, victim, bully-victim, provocative victim, passive victim, bystander, upstander, etc.). The variability of definitions in both fields is a problem for researchers and practitioners alike, and, until a federal set of standardized definitions and procedures are agreed upon, the definitional quagmire will continue to present challenges.

\section{Disability Labels}

While the observable nature of some disabilities may serve as a predictor for increased involvement in bullying (Dawkins, 1996; Swearer et al., 2012), overt differences between an individual and his or her peer group also place the individual at a greater risk for involvement, regardless of disability status (Estell et al., 2009; Horowitz et al., 2004; Whitney et 
al., 1994). Therefore, understanding bullying among students with disabilities is more complex than making a dichotomous distinction between students with and without disabilities or placing students into arbitrary groups based on a common characteristic (e.g., observability, severity, class placement; Rose, 2010; Rose, Allison, \& Simpson, 2012; Rose \& Monda-Amaya, 2012). Students are traditionally identified with a disability through a referral and assessment process whereby a multidisciplinary team evaluates current levels of academic and/or behavioral functioning and makes a disability determination based on specific diagnostic criteria (Overton, 2009). The Individuals with Disabilities Education Improvement Act (2004) defines disability as intellectual disabilities, hearing impairments (including deafness), speech or language impairments, visual impairments (including blindness), emotional disturbance (ED), orthopedic impairments, autism, traumatic brain injury (TBI), other health impairments (OHI), specific learning disabilities (SLD), and developmental delays (ages 3 through 9) that require special education or related services (P.L. 108-446, § 602, Stat. 2652). Although the federal definition includes several classifications of disabilities, each disability classification maintains different diagnostic criteria and requires varying levels of supports and services (Yell, Shriner, \& Katsiyannis, 2006).

\section{At-Risk Characteristics}

If simply diverging from peer group norms serves as a predictor for increased involvement in bullying (Horowitz et al., 2004; Whitney et al., 1994), an infinite number of risk factors can be associated with students who receive special education services. While any number of variables could serve as risk factors, research suggests that students with disabilities are at an increased risk due to physical attributes, personal characteristics, and school-related factors (Horowitz et al., 2004; McLaughlin et al., 2010; Rose \& Monda-Amaya, 2012). Therefore, these factors are central to understanding the overrepresentation of students with disabilities who are involved in bullying.

Disability status falls on a continuum, and students may possess characteristics specific to the disability that may place them at greater risk for involvement in bullying. For example, the stuttering, stammering, or vocal cadence of individuals with speech or language impairments (Davis, Howell, \& Cooke 2002; Hugh-Jones \& Smith, 1999, Knox \& Conti-Ramsden, 2003; Sweeting \& West, 2001); the unique gait of individuals with orthopedic impairments (Llewellyn, 2000; Nadeau \& Tessier, 2006; Whitney et al., 1994; Yude, Goodman, \& McConachie, 1998); the use of sign language or hearing aids for individuals with hearing impairments (Dixon, 2006; Dixon, Smith, \& Jenks, 2004; Kent, 2003; Weiner \& Miller, 2006; Whitney et al., 1994); and the use of

\section{Disability Labels Case Example}

In spring of 2012, the father of a 10-year-old boy with autism put a recording device on his son's wheelchair before he went to school (Johnston, 2012). He had noticed a change in his son's behavior and wondered what was going on in the classroom. The wiretap allegedly recorded the teachers calling his son derogatory names and saying abusive things to him. The father stated that he felt the school did not address his concerns when he played the audio recording of the teachers talking abusively toward his son. He subsequently posted the audio clips on YouTube and filed an online petition to get teachers who bully children fired. This example illustrates the helpless and angry feelings that many parents have regarding the treatment of their children with physical and mental disabilities.

However, students with specific learning disabilities (Martlew \& Hodson, 1991; Nabuzoka, 2003; Nabuzoka \& Smith, 1993; Sabornie, 1994; Whitney et al., 1994), Asperger syndrome (Little, 2002), ED (Monchy, Pijl, \& Zandberg, 2004), and more significant intellectual disabilities (Whitney et al., 1994) may be subjected to increased involvement in bullying based on perceived differences in academic, functional, and/or social skills (McLaughlin et al., 2010; Rose, Monda-Amaya, \& Espelage, 2011; Swearer et al., 2012). By definition, however, students who have been identified with a disability receive some level of special education or related services, which differentiates them from students without disabilities and may place them at greater risk for involvement in bullying.

glasses, brailled text, or large print media for individuals with visual impairments (Horowitz et al., 2004) may lead to increased mimicking and name calling specific to the overt characteristics of the disability (McLaughlin et al., 2010; Rose, 2010; Rose et al., 2012).

\section{Personal Characteristics}

The phenomenon of bullying is complex and is influenced by the social interplay between perpetration and victimization as a result of cumulative factors among and within individuals, families, peer groups, schools, communities, and cultures (for reviews see Espelage \& Swearer, 2009; Hong \& Espelage, 2012; Swearer \& Espelage, 2004). By definition, students with disabilities receive special education services that their peers without disabilities do not receive, yet many studies on bullying fail to examine significant predictors that include other potential risk factors not directly attributable to a child's disability. Reiter and LapidotLefler (2007) found that "being a victim was correlated with emotional problems and interpersonal problems" (p. 179) 
and students with disabilities often struggle with these social relationships because they may lack age-appropriate social skills (see Baker \& Donelly, 2001; Doren, Bullis, \& Benz, 1996; Kaukiainen et al., 2002; Llewellyn, 2000; Woods \& Wolke, 2004) or have language and communication deficits (Knox \& Conti-Ramsden, 2003, McLaughlin et al., 2010).

Several hypotheses have associated the escalated rates of victimization among students with disabilities with challenges in the social and interpersonal domains. According to Sabornie (1994), victims of bullying are often passive, exhibit timid responses, misread nonverbal communication, or misinterpret nonthreatening cues within social interactions. Passivity in interpersonal interactions along with misinterpretation of another's intent or communication may elicit aggressive responses from peers. At the same time, students with disabilities may be at greater risk for victimization because they might not have the social sophistication to prevent victimization, such as using humor or sarcasm (Nabuzoka, 2003). This lack of socializing behaviors may also lead to the victim's inability to develop close friendships, rejection from classroom peers, low self-esteem, anxiety, and a perception of dependence on adult assistance (Baker \& Donelly, 2001; Dockrell \& Lyndsay, 2000; Kaukiainen et al., 2002; Llewellyn, 2000; Martlew \& Hodson, 1991; McLaughlin et al., 2010; Morrison, Furlong, \& Smith, 1994; Nabuzoka \& Smith, 1993). Indeed, research suggests that, when students with disabilities display age-appropriate social skills and positive self-concept, are academically independent, maintain quality relationships, and are actively engaged in classroom and school activities, they are less likely to be targets of bullying (Flynt \& Morton, 2004; Kumpulainen et al., 1998; Martlew \& Hodson, 1991; Mishna, 2003; Whitney et al., 1994).

In an recent interview study of 15 teachers and observational study of 24 students in grades 4 through 7 , students with disabilities engaged in less positive roles (Challenged Learner, Victim, Bully), while students without disabilities engaged in more positive roles (Independent Learner, Nurturer, Friend; Specht, King, Servais, Kertoy, \& Spencer, 2011). Some of the same risk factors associated with victimization are often thought to contribute to risk of bully perpetration. Rose, Monda-Amaya, and Espelage (2011) argued, "bullying perpetration by students with disabilities is often a learned behavior, possibly a reaction to prolonged victimization, or an overall lack of social skills" (p. 125). Although perpetration may be a learned behavior, social skills deficits may also indicate that students with disabilities who engage in bully perpetration could have social information processing deficits (Crick \& Dodge, 1994; Crick \& Dodge, 1996; Dodge et al., 2003). More specifically, a lack of social skills may be related to the lack of assertion, a lack of self-control, or both (Mayer \& Leone, 2007). Students with disabilities might also misread social cues (Whitney et al., 1994), misinterpret social stimuli, or respond with aggression toward peers (Sabornie, 1994). Additionally, lack of social skills may also lead students with disabilities to misinterpret rough and tumble play as a physical attack and thus may respond inappropriately with aggressive behavior (Nabuzoka \& Smith, 1999).

\section{School-Related Factors}

In addition to personal characteristics, school-related factors can serve as predictors for increased involvement in the bullying dynamic for students with disabilities. According to the federal definition (IDEIA, 2004), students are identified with a disability based on their need for special education or related services. These services, however, serve as a fundamental difference between students with and without disabilities, where students with disabilities require increased academic and/or functional accommodations (Rose, 2010; Rose et al., 2012). While academic difficulties may be a predictor of increased involvement in the bullying dynamic (McLaughlin et al., 2010; Singer, 2005; Whitney et al., 1994; Yude \& Goodman, 1999), the overt nature of these special education services may increase the perception of dependence on teacher or adult assistance (Baker \& Donelly, 2001; Llewellyn, 2000; Nabuzoka \& Smith, 1993; Rose, 2010).

The provisions of IDEIA (2004) also allow for a continuum of services for students with disabilities as defined by the student's least restrictive environment (Smith, 2007). Therefore, accommodations provided to students with disabilities are individualized, where they can receive special education services in a variety of settings (e.g., inclusion, self-contained classroom, segregated schools) or a combination of settings (Rose, 2010; Rose et al., 2012; Salend, 2008; Smith, 2007). While a continuum of services may be necessary for academic success, research suggests that, as the restrictiveness of the placement increases, victimization (Martlew \& Hodson, 1991; Morrison et al., 1994; O'Moore \& Hillery, 1989; Sabornie, 1994) and perpetration (O'Moore \& Hillery, 1989; Rose et al., 2009; Whitney, Nabuzoka, \& Smith, 1992) also increase. These discrepant rates could be attributed to the positive aspects of inclusive practices such as positive behavior modeling, acquisition of social skills, increased social and academic development (Brown et al., 1989), increased acceptance, reduction in negative stereotypes (Martlew \& Hodson, 1991), and increased participation in classroom activities (Sabornie, 1994). Overall, inclusive practices could serve as a vehicle for students with disabilities to learn, practice, and validate social skills among peers and classmates (Mishna, 2003). 


\section{Inclusive Practices Case Example}

Lunch Bunch has been part of Lincoln East High School 's culture for nearly 10 years. Lincoln East is one of six high schools in Lincoln, Nebraska, and educates 1,500 students in grades 9-12. Every Thursday, students from around the school gather for lunch to share their own stories and to learn from each other. Lunch Bunch is intentional in welcoming ALL students without regard to any defining characteristic but with special attention to students with disabilities. Every week during introductions, participants discover the many things they have in common, along with their unique and special contributions. The goal of this this weekly activity is that students will be kinder, more accepting peers and will develop a kinder, more accepting school culture, leading to real friendships and to a climate of acceptance for everyone. Already, many of the participants attend school activities together, including homecoming dances and prom, and Lunch Bunch students have cheered at the school's Special Olympics basketball games. Last year's prom king was from Lunch Bunch! Laurie Witters-Churchill, chair of the Department of Special Education at Lincoln East High School, founded Lunch Bunch and a student advisory committee has led Lunch Bunch for the past decade. For more information about Lunch Bunch please see http:// journalstar.com/news/local/lunch-bunch-taking-mysteryout-of-lincoln-east-hallway/article_fa31a6a8-77f8-50c18935-6833395522c5.html.

\section{DISABILITY-BASED BULLYING: IMPLICATIONS FOR SCHOOL PERSONNEL}

On October 26, 2010, the United States Department of Education's Office for Civil Rights released a Dear Colleague letter that outlines disability harassment under Section 504 and Title II (see appendix A for review). If school personnel fail to realize that the bullying is disability-based harassment, the school is in noncompliance under Section 504 and Title II. However, the stipulations in the law focus on the individuals who are being bullied. What if the bullying behavior is related to the student's disability status?

\section{Placement for Students with Conduct Disorders and Oppositional Defiant Disorders}

According to the DSM-IV-TR, one criterion for a diagnosis of conduct disorder is "often bullies, threatens or intimidates others" (APA, 2000). Excessive levels of bullying are also a criterion for conduct disorders in the ICD-10 (WHO, 2010), published by the World Health Organization and used in more than 100 countries worldwide. $I C D$ codes are the system used by private practices and hospitals. So, in the case of a diagnosis of conduct disorder, the behavior of bullying is actually a symptom of the disorder. This presents quite a conundrum for schools with students with emotional and behavioral disorders (EBD), some of whom will be diagnosed with conduct disorder. As Maag and Katsiyannis (2012) noted, students with EBD are more likely to perpetrate bullying behaviors.

In a recent study of 163 middle school students identified with specific disability labels, Rose and Espelage (2012) found that students with EBD reported significantly higher levels of bullying and fighting than other subgroups of students, including those identified with specific learning disability, low incidence disability, and speech or language impairment. In addition, higher levels of anger predicted higher levels of bully perpetration for students with EBD, whereas higher levels of victimization predicted higher levels of bully perpetration for students with disabilities other than an EBD. Therefore, it appears that the bullying by a student with EBD might not be in reaction to victimization, but might be direct aggression, as suggested by the DSM-IV-TR and ICD-10 criteria. Students with diagnoses other than EBD could be classified as reacting to victimization and therefore are more characteristic of bully-victims (Rose, 2010).

\section{Victimization and Students with Disabilities}

While students with disabilities are legally placed in their least restrictive environments, research on victimization among students with disabilities suggests that disability status is a predictor for increased victimization (McLaughlin et al., 2010; Rose, 2010; Rose, Monda-Amaya, \& Espelage, 2011). For example, when disability status is viewed in terms of a dichotomy (i.e., presence or absence of disability) or by creating arbitrary groupings, research suggests that students with disabilities are victimized at least twice as often as their peers without disabilities (Dawkins, 1996; Kaukiainen et al., 2002; Monchy et al., 2004; Nabuzoka \& Smith, 1993; Rose, Espelage, Aragon, \& Elliott, 2011; Rose et al., 2009). However, as previously stated, understanding victimization among students with disabilities is more complex than simple dichotomies or arbitrary groups.

In their seminal work, Whitney and colleagues (1994) investigated the victimization rates of a demographically matched peer group of 93 students with various disabilities and 93 students without disabilities in inclusive settings. While it was determined that students with disabilities were victimized more than their demographically matched peer group, it was also determined that victimization varied between subgroups of students with disabilities. Specifically, Whitney and colleagues (1994) determined that students with mild to moderate learning difficulties were up to three 
times more likely and students with physical disabilities and hearing impairments were up to four times more likely to be victimized when compared to their peers without disabilities.

While a dearth of literature specific to the victimization of individual subgroups of students with disabilities exists, Whitney and colleagues' (1994) work has been extended to include various disability categories. Recent empirical investigations have suggested that victimization may be predicted by the severity of the disability (Rose, 2010). For example, students with autism may be victimized more (Bejerot \& Mörtberg, 2009; Little, 2002), and students with learning disabilities may be victimized less than other subgroups of students with disabilities (Wallace, Anderson, Bartholomay, \& Hupp, 2002; White \& Loeber, 2008). Unfortunately, much of the extant literature varies on victimization rates of individual subgroups of students with disabilities, making direct subgroup comparisons difficult (Rose, 2010).

\section{Comorbidity and Double Minority Stress}

According to McLaughlin and colleagues, "Children with co-morbid conditions report higher levels of peer victimization" (2010, p. 22). Students with disabilities can have comorbid conditions when they have been identified with a primary and secondary disability label. Several studies have determined that the existence of comorbid conditions serves as a stronger predictor for increased victimization when compared to students with a single disability (see Bejerot \& Mörtberg, 2009; Sweeting \& West, 2001). However, this distinction is not exclusive to disability labels or psychiatric labels but can extend to any at-risk characteristic (e.g., sexual orientation, religious affiliation, poverty, etc.). Therefore, we consider the possession of dual at-risk characteristics as double minority stress.

\section{Case Example of Double Minority Stress}

Described as a compassionate and loving student, Asher Brown was a 13-year-old eighth grader with Asperger syndrome, who was allegedly subjected to incessant verbal and physical bullying from his classmates. This victimization stemmed from his sexual orientation, religion, and disability status. The pervasive victimization, which culminated with one of Asher's peers kicking him down a flight of stairs and knocking his books out of his hands, prompted his suicidal ideations. In Asher's final hours, he informed his father that he was gay, and soon thereafter died from a self-inflected gunshot wound (O'Hare, 2010).

\section{RESEARCH TO PRACTICE GAP}

While understanding escalated rates of bullying involvement in terms of disability labels and double minority stress is fundamentally important, educational practices for students with disabilities are not solely founded in disability identification. As previously stated, IDEIA (2004) allows for a continuum of services for students with disabilities based on their least restrictive environment (Smith, 2007). Therefore, consideration must be given to both disability labels and class placement. At the present time, research has established that students with disabilities are overrepresented within the bullying dynamic and levels of involvement may be partially attributed to the severity of the disability (McLaughlin et al., 2010; Rose, Monda-Amaya, \& Espelage, 2011). Additionally, empirical evidence suggests that the restrictiveness of classroom placement and teacher practices also serve as a predictors of escalated rates of involvement, where students in more restrictive environments are at risk for increased victimization (Espelage et al., in press; Martlew \& Hodson, 1991; Morrison et al., 1994; Rose et al., 2009; Sabornie, 1994); however, school climate may moderate this relationship, as the "Lunch Bunch" example demonstrated. It can be argued that, as the severity of the disability increases, the restrictiveness of the class placement also increases (Rose, 2010; Rose et al., 2012). Unfortunately, few studies have explored the intersection between disability labels, double minority stress, class placement, and teacher practices, which points to a notable gap in the extant literature base. Interpretations of the current body of literature would suggest that both severity of the disability and restrictiveness of placement serve as similar predictors for involvement. However, future research endeavors should attempt to disentangle the predictive nature of disability labels, double minority stress, and class placement.

\section{IMPLICATIONS FOR BULLYING PREVENTION AND INTERVENTION}

Raskauskas and Modell (2011) noted that existing antibullying programs do not have modifications for students with disabilities. They list several widely used programs but state that, for effective bullying prevention and intervention, all stakeholders need to feel included. Students with disabilities are an important stakeholder, too often excluded from whole-school programming. The Pacer Center's National Bullying Prevention Center has some excellent resources for bullying prevention and intervention that address students with disabilities (www.pacer.org), and AbilityPath has supports for parents of children with special needs (www.abilitypath.org). These online resources can help parents and 
teachers of exceptional children. Regardless of ability, bullying prevention and intervention programming needs to target ALL students. School personnel should consider ways programming can be modified for students with disabilities at the school, classroom, and individual levels (Espelage et al., in press; Lane, Kalberg, \& Menzies, 2009; Rose et al., 2012; Rose \& Monda-Amaya, 2012). For example, an interpreter can be provided for any assembly or play; closed captioning can be used for videos; braille and enlarged type can be used for students with visual impairments; social stories can be used to increase social skill acquisition; structured cooperative learning groups can be used for behavioral modeling; specific, concrete, and less abstract concepts can be used with students with intellectual disabilities; and examples that include students with disabilities can help make antibullying messaging more relevant for all students.

\section{DIRECTIONS FOR FUTURE RESEARCH}

As is evident from this review of the literature, there are many directions for future research in the area of bullying and students with disabilities. We have much to learn. While research suggests that severity of disability is related to bullying involvement, what is the role of school climate? Does a positive and healthy school climate mediate bullying and victimization experiences? In terms of double minority stress, how does experiencing more than one disability status impact involvement in bullying? In terms of both externalizing behaviors (i.e., conduct disorder) and internalizing behaviors (i.e., depression), how might this additive effect influence involvement in bullying and victimization? Finally, we need to assess whether antibullying programs effectively impact students in special education or whether modifications need to be made. Creating caring and supportive schools free from bullying and cruel behavior will improve the educational system for all.

\section{REFERENCES}

AbilityPath.org (2011). Walk a mile in their shoes: Bullying and the child with special needs. A report and a guide from AbilityPath.org. Retrieved from http://www.abilitypath.org/areas-of-development/ learning — schools/bullying/articles/walk-a-mile-in-their-shoes.pdf

American Psychiatric Association. (APA). (2000). Diagnostic and statistical manual of mental disorders (4th ed., text rev.). Washington, DC: Author.

Baker, K., \& Donelly, M. (2001). The social experiences of children with disabilities and the influence of environment: A framework for intervention. Disability \& Society, 16, 71-85. doi: 10.1080/ 713662029

Baumeister, A. L., Storch, E. A., \& Geffken, G. R. (2008). Peer victimization in children with learning disabilities. Child and Adolescent Social Work Journal, 25, 11-23. doi:10.1007/s10560-007-0109-6

Bazelon, E. (2012, March 29). The problem with Bully: The new documentary dangerously oversimplifies the connection between bullying and suicide. Slate. Retrieved from http://www.slate.com/ articles/news_and_politics/bulle/2012/03/bully_documentary_lee_ hirsch_s_film_dangerously_oversimplifies_the_connection_betwe en_bullying_and_suicide_.html

Bejerot, S., \& Mörtberg, E. (2009). Do autistic traits play a role in the bullying of obsessive-compulsive disorder and social phobia sufferers? Psychopathology, 42, 170-176. doi: 10.1159/000207459

Brown, L., Long, E., Udvari-Solner, A., Schwarz, P., VanDeventer, P., Ahlgren, C., et al. (1989). Should students with severe intellectual disabilities be based in regular or in special education classrooms in home schools? The Journal of the Association for Persons with Severe Handicaps, 14, 8-13.

Crick, N. R., \& Dodge, K. A. (1994). A review and reformulation of social information-processing mechanisms in children's social adjustment. Psychological Bulletin, 115, 74-101. doi: 10.1037/ 0033-2909.115.1.74

Crick, N. R., \& Dodge, K. A. (1996). Social information-processing mechanisms in reactive and proactive aggression. Child Development, 67, 993-1002. doi:10.1111/j.1467-8624.1996.tb01778.x

Davis, S., Howell, P., \& Cooke, F. (2002). Sociodynamic relationships between children who stutter and their non-stuttering classmates. Journal of Child Psychology and Psychiatry, 43, 939-947. doi: 10.1111/1469-7610.00093

Dawkins, J. L. (1996). Bullying, physical disability and the paediatric patient. Developmental Medicine \& Child Neurology, 38, 603612. doi:10.1111/j.1469-8749.1996.tb12125.x

Dixon, R. (2006). A framework for managing bullying that involves students who are deaf or hearing impaired. Deafness and Education International, 8, 11-32. doi:10.1179/146431506790560238

Dixon, R., Smith, R., \& Jenks, C. (2004). Bullying and difference: A case study of peer group dynamics in one school. Journal of School Violence, 3(4), 41-58. doi:10.1300/J202v03n04_03

Dockrell, J., \& Lyndsay, G. (2000). Meeting the needs of children with specific speech and language difficulties. European Journal of Special Needs Education, 15, 24 41. doi:10.1080/088562500361682

Dodge, K. A., Lansford, J. E., Burks, V. S., Bates, J. E., Pettit, G. S., Fontaine, R., et al. (2003). Peer rejection and social informationprocessing factors in the development of aggressive behavior problems in children. Child Development, 74, 374-393. doi:10.11 11/1467-8624.7402004

Doren, B., Bullis, M., \& Benz, M. R. (1996). Predictors of victimization experiences of adolescents with disabilities in transition. Exceptional Children, 63, 7-18.

Espelage, D. L., Anderman, E., Brown, V., Jones, A., Lane, K., McMahon, S. D., ... \& Reynolds, C. R. (in press). Understanding and preventing violence directed against teachers: Recommendations for a national research, practice, and policy agenda. American Psychologist.

Espelage, D. L., \& Swearer, S. M. (2009). Contributions of three social theories to understanding bullying perpetration and victimization among school-aged youth. In M. J. Harris (Ed.), Bullying, rejection, and peer victimization: A social cognitive neuroscience perspective (pp. 151-170). New York: Springer.

Estell, D. B., Farmer, T. W., Irvin, M. J., Crowther, A., Akos, P. et al. (2009). Students with exceptionalities and the peer group context of bullying and victimization in late elementary school. Journal of Child and Family Studies, 18(2), 136-150. doi:10.1007/s10826008-9214-1

Flynt, S. W., \& Morton, R. C. (2004). Bullying and children with disabilities. Journal of Instructional Psychology, 31, 330-333. 
Hong, J. S., \& Espelage, D. L. (2012). A review of research on bullying and peer victimization in school: An ecological system analysis. Aggressive and Violent Behavior, 17, 311-322. doi:10.1016/j. avb.2012.03.003

Horowitz, J. A., Vessey, J. A., Carlson, K. L., Bradley, J. F., Montoya, C., McCullough, B., \& David, J. (2004). Teasing and bullying experiences of middle school students. Journal of the American Psychiatric Nurses Association, 10(4), 165-172. doi: 10.117/1078 390304267862

Hugh-Jones, S., \& Smith, P. K. (1999). Self-reports of short and long term effects of bullying and children who stammer. British Journal of Educational Psychology, 69, 141-158. doi:10.1348/0007 09999157626

Humphrey, J. L., Storch, E. A., \& Geffken, G. R. (2007). Peer victimization in children with attention-deficit hyperactivity disorder. Journal of Child Health Care, 11, 248-260. doi:10.1177/13674 93507079571

Individuals with Disabilities Education Improvement Act of 2004, H.R. 1350, 108th Congress, P.L. No. 108-446, § 1 et seq., 118 Stat. 2647 (2004).

Johnston, I. (2012, April 26). Autistic boy's father: Why hasn't teacher been fired over "bullying"? U.S. News. Retrieved from http:// usnews.nbcnews.com/_news/2012/04/26/11395270-autistic-boysfather-why-hasnt-teacher-been-fired-over-bullying?lite

Kaukiainen, A., Salmivalli, C., Lagerspetz, K., Tamminen, M., Vauras, M., Mäki, H., et al. (2002). Learning difficulties, social intelligence, and self-concept: Connections to bully-victim problems. Scandinavian Journal of Psychology, 43, 269-278. doi:10.1111/ 1467-9450.00295

Kent, B. A. (2003). Identity issues for hard-of-hearing adolescents aged 11,13 , and 15 in mainstream settings. Journal of Deaf Studies and Deaf Education, 8, 315-324. doi:10.1093/deafed/eng017

Knox, E., \& Conti-Ramsden, G. (2003). Bullying risks of 11 -year-old children with specific language impairment (SLI): Does school placement matter? International Journal of Language \& Communication Disorders, 38, 1-12. doi:10.1080/13682820304817

Kumpulainen, K., Räsänen, E., Henttonen, I., Almqvist, F., Kresanov, K., Linna, S.-L., et al. (1998). Bullying and psychiatric symptoms among elementary school-age children. Child Abuse \& Neglect, 22, 705-717. doi:10.1016/S0145-2134(98)00049-0

Lane, K. L., Kalberg, J. R., \& Menzies, H. M. (2009). Developing school-wide programs to prevent and manage problem behaviors: A step-by-step approach. New York: Guilford Press.

Little, L. (2002). Middle-class mothers' perceptions of peer and sibling victimization among children with Asperger's syndrome and nonverbal learning disorders. Issues in Comprehensive Pediatric Nursing, 25, 43-57. doi:10.1080/014608602753504847

Llewellyn, A. (2000). Perceptions of mainstreaming: A systems approach. Developmental Medicine \& Child Neurology, 42, 106 115. doi:10.1017/S0012162200000219

Maag, J. W., \& Katsiyannis, A. (2012). Bullying and students with disabilities: Legal and practice considerations. Behavioral Disorders, $37,78-86$.

Marini, Z. A., Fairbairn, L., \& Zuber, R. (2001). Peer harassment in individuals with developmental disabilities: Towards the development of a multi-dimensional bullying identification model. Developmental Disabilities Bulletin, 29, 170-195.

Martlew, M., \& Hodson, J. (1991). Children with mild learning difficulties in an integrated and in a special school: Comparisons of behaviour, teasing, and teachers' attitudes. The British Journal of Educational Psychology, 61, 355-372. doi:10.1111/j.2044-8279. 1991.tb00992.x

Mayer, M. J., \& Leone, P. E. (2007). School violence and disruption revisited: Equity and safety in the school house. Focus on Exceptional Children, 40, 1-28.

McLaughlin, C., Byers, R., \& Vaughn, R. P. (2010). Responding to bullying among children with special educational needs and/or disabilities. London: Anti-Bullying Alliance.

Mishna, F. (2003). Learning disabilities and bullying: Double jeopardy. Journal of Learning Disabilities, 36, 336-347. doi:/10.1177/0022 2194030360040501

Monchy, M. D., Pijl, S. J., \& Zandberg, T. (2004). Discrepancies in judging social inclusion and bullying of pupils with behaviour problems. European Journal of Special Needs Education, 19, 317-330. doi:10.1080/0885625042000262488

Morrison, G. M., Furlong, M. J., \& Smith, G. (1994). Factors associated with the experience of school violence among general education, leadership class, opportunity class, and special day class pupils [Electronic Version]. Education \& Treatment of Children, 17, 356-369.

Nabuzoka, D. (2003). Teacher ratings and peer nominations of bullying and other behaviour of children with and without learning difficulties. Educational Psychology, 23, 307-321. doi:10.1080/01443 41032000060147

Nabuzoka, D., \& Smith, P. K. (1993). Sociometric status and social behaviour of children with and without learning difficulties. Journal of Child Psychology and Psychiatry, 34, 1435-1448. doi:10. 1111/j.1469-7610.1993.tb02101.x

Nabuzoka, D., \& Smith, P. K. (1999). Distinguishing serious and playful fighting by children with learning disabilities and nondisabled children. Journal of Child Psychology and Psychiatry, 40, 883890. doi:10.1111/1469-7610.00506

Nadeau, L., \& Tessier, R. (2006). Social adjustment of children with cerebral palsy in mainstream classes: Peer perception. Developmental Medicine and Child Neurology, 48, 331-336. doi:10.1017/ S0012162206000739

O’Hare, Peggy (2010, September 27). Parents: Bullying drove Cy-Fair 8th-grader to suicide. Houston Chronicle. Retrieved from http:// www.chron.com/life/mom-houston/article/Parents-Bullying-droveCy-Fair-8th-grader-to-1698827.php

O'Moore, A. M., \& Hillery, B. (1989). Bullying in Dublin schools. The Irish Journal of Psychology, 10, 426-441.

Overton, T. (2009). Assessing learners with special needs: An applied approach (6th ed.) Upper Saddle River, NJ: Merrill Pearson.

Raskauskas, J., \& Modell, S. (2011). Modifying anti-bullying programs to include students with disabilities. Teaching Exceptional Children, 44, 60-67.

Reiter, S., \& Lapidot-Lefler, N. (2007). Bullying among special education students with intellectual disabilities: Differences in social adjustment and social skills. Intellectual and Developmental Disabilities, 3, 174-181. doi:10.1352/1934-9556(2007)45[174:BA

Rose, C. A. (2010). Bullying among students with disabilities: Impact and implications. In D. L. Espelage \& S. M. Swearer (Eds.), Bullying in North American schools: A socio-ecological perspective on prevention and intervention (2nd ed., pp. 34 44). Mahwah, $\mathrm{NJ}$ : Erlbaum.

Rose, C. A., Allison, S., \& Simpson, C. G. (2012). Addressing bullying among students with disabilities within a multi-tiered educational 
environment. In D. W. Hollar (Ed.), Handbook of children with special health care needs (pp. 383-397). New York: Springer. doi: 10.1007/978-1-4614-2335-5_20.

Rose, C. A., \& Espelage, D. L. (2012). Risk and protective factors associated with the bullying involvement of students with emotional and behavioral disorders. Behavioral Disorders, 37, 133-148.

Rose, C. A., Espelage, D. L., Aragon, S. R., \& Elliott, J. (2011). Bullying and victimization among students in special education and general education curricula. Exceptionality Education International, 21(3), 2-14.

Rose, C. A., Espelage, D. L., \& Monda-Amaya, L. E. (2009). Bullying and victimization rates among students in general and special education: A comparative analysis. Educational Psychology, 29, 761-776. doi:10.1080/01443410903254864

Rose, C. A., \& Monda-Amaya, L. E. (2012). Bullying and victimization among students with disabilities: Effective strategies for classroom teachers. Intervention in School and Clinic, 48, 99-107. doi: $10.1177 / 1053451211430119$.

Rose, C. A., Monda-Amaya, L. E., \& Espelage, D. L. (2011). Bullying perpetration and victimization in special education: A review of the literature. Remedial and Special Education, 32, 114-130. doi: $10.1177 / 0741932510361247$

Sabornie, E. J. (1994). Social-affective characteristics in early adolescents identified as learning disabled and nondisabled. Learning Disability Quarterly, 17, 268-279. doi:10.2307/1511124

Salend, S. J. (2008). Creating inclusive classrooms: Effective and reflective practices (6th ed.). Upper Saddle River, NJ: Pearson.

Sánchez, C., \& Cerezo, F. (2010). Personal and social characteristics of schoolchildren involved in building in primary education. Electronic Journal of Research in Educational Psychology, 8(3), 1015-1032.

Saylor, C. F., \& Leach, J. B. (2009). Perceived bullying and social support in students accessing special inclusion programming. Journal of Developmental and Physical Disabilities, 21, 69-80. doi:10.10 07/s10882-008-9126-4

Smith, D. D. (2007). Introduction to special education: Making a difference (6th ed.). Boston: Pearson.

Singer, E. (2005). The strategies adopted by Dutch children with dyslexia to maintain their self-esteem when teased at school. Journal of Learning Disabilities, 38, 411-423. doi:10.1177/002221940 50380050401

Specht, J. A., King, G. A., Servais, M., Kertoy, M., \& Spencer, T. (2011). School roles: A way to investigate participation. Exceptionality Education International, 21(1), 2-14.

Swearer, S. M., \& Espelage, D. L. (2004). Introduction: A social-ecological framework of bullying among youth. In D. L. Espelage \& S. M. Swearer (Eds.), Bullying in American schools (pp. 1-11). Mahwah, NJ: Erlbaum.
Swearer, S. M., Wang, C., Maag, J. W., Siebecker, A. B., \& Frerichs, L. J. (2012). Understanding the bullying dynamic among students in special and general education. Journal of School Psychology, 50, 503-520. doi:10.1016/j.jsp.2012.04.001

Sweeting, H., \& West, P. (2001). Being different: Correlates of the experience of teasing and bullying at age 11. Research Papers in Education, 16, 225-246. Retrieved from http://eprints.gla.ac.uk/ archive/00002724/

Thompson, D., Whitney, I., \& Smith, P. K. (1994). Bullying of children with special needs in mainstream schools. Support for Learning, 9, 103-106. doi:10.1111/j.1467-9604.1994.tb00168.x

Wallace, T., Anderson, A. R., Bartholomay, T., \& Hupp, S. (2002). An ecobehavioral examination of high school classrooms that include students with disabilities. Exceptional Children, 68, 345-359.

Weiner, M. T., \& Miller, M. (2006). Deaf children and bullying: Directions for future research. American Annals of the Deaf, 151, 61-70. doi:10.1353/aad.2006.0021

White, N. A., \& Loeber, R. (2008). Bullying and special education as predictors of serious delinquency. Journal of Research in Crime and Delinquency, 45, 380-397. doi:10.1177/0022427808322612

Whitney, I., Nabuzoka, D., \& Smith, P. K. (1992). Bullying in schools: Mainstream and special needs. Support for Learning, 7, 3-7. doi: 10.1111/j.1467-9604.1992.tb00445.x

Whitney, I., Smith, P. K., \& Thompson, D. (1994). Bullying and children with special educational needs. In P. K. Smith \& S. Sharp (Eds.), School bullying: Insights and perspectives (pp. 213-240). London: Routledge.

Woods, S., \& Wolke, D. (2004). Direct and relational bullying among primary school children and academic achievement. Journal of School Psychology, 42, 135-155. doi:10.1016/j.jsp.2003.12.002

World Health Organization. (WHO). (2010). International statistical classification of diseases and related health problems (10th rev.). Geneva: Author.

Yell, M. L., Shriner, J. G., \& Katsiyannis, A. (2006). Individuals with disabilities education improvement act of 2004 and IDEA regulations of 2006: Implications for educators, administrators, and teacher trainers. Focus on Exceptional Children, 39, 1-13.

Yude, C., \& Goodman, R. (1999). Peer problems of 9- to 11 -year-old children with hemiplegia in mainstream schools: Can these be predicted? Developmental Medicine and Child Neurology, 41, 4-8. doi: $10.1017 / \mathrm{S} 001216229900002 \mathrm{X}$

Yude, C., Goodman, R., \& McConachie, H. (1998). Peer problems of children with hemiplegia in mainstream primary schools. Journal of Child Psychology and Psychiatry, 39, 533-541. doi.10.1017/ S002196309800239X 


\section{APPENDIX A: SYNOPSIS OF DEAR COLLEAGUE LETTER}

On October 26, 2010, the United States Department of Education's Office for Civil Rights issued a Dear Colleague Letter addressing the potential intersection of bullying and federal antidiscrimination laws. More specifically, the letter reiterates the necessity of recognizing Title VI of the Civil Rights Act of 1964 (42 U.S.C. $\S 2000$ d et seq.), Title IX of the Education Amendments of 1972 (20 U.S.C. $\S 1681$ et seq.), Section 504 of the Rehabilitation Act of 1973 (29 U.S.C. § 794), and Title II of the Americans with Disabilities Act of 1990 (42 U.S.C. § 12131 et seq.), which, in sum, prohibit discrimination based on race, color, national origin, sex, or disability. Therefore, the Office of Civil Rights contends that bullying or harassment based on the aforementioned characteristics may be a violation of both the school or district's antibullying policy and federal civil rights laws.

The letter states schools are legally responsible for addressing harassment, even if identified as bullying by the school, based on race, color, national origin, sex, or disability; where schools must take swift and immediate action to investigate and rectify allegations and incidence of these identified areas of harassment. It should be noted that consequences provided should not penalize the victim and should impede the victim's educational program to the least possible extent. Thus, school administrators and policy makers who design provisions that call for the separation of the harasser and victim should be cognizant of the separation process to ensure the victim is not required to make drastic educational changes as a measure of harassment reduction or prevention. These policy makers should, however, ensure that schools are taking measures to prevent further harassment and retaliation against the victim or reporter(s). Most importantly, the Office of Civil Rights explains that schools must recognize that the nature of the misconduct, not the general labeling of the behavior, should determine response actions; and when civil rights laws are violated, schools should evaluate school climate, which may require teacher or community training or additional policies to ensure the prevention and elimination of harassment. The Dear Colleague Letter also includes hypothetical scenarios to reiterate and solidify the Office of Civil Rights' position on harassment based on race, color, national origin, gender, and disability. For more information, the full Dear Colleague Letter can be found on the Office of Civil Rights's webpage at http://www2.ed. gov/about/offices/list/ocr/letters/colleague-201010.html. 


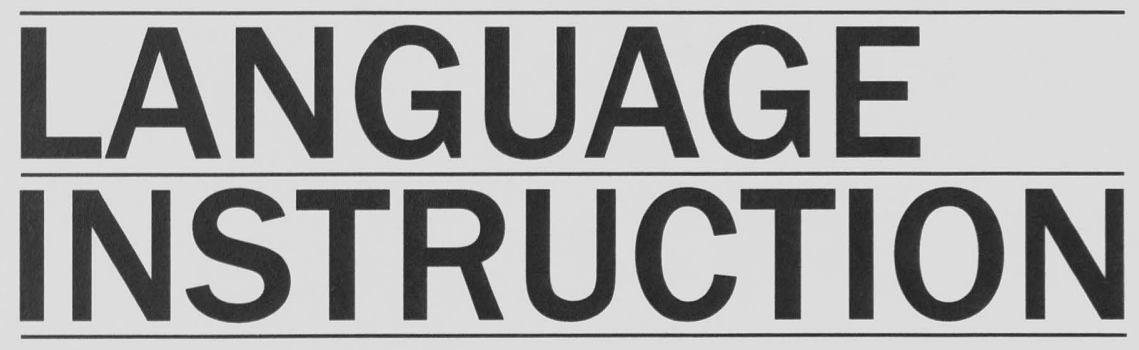

\section{FOR STUDENTS WITH DISABILITIES} Fourth Edition

\section{Edward A. Polloway, Lynda Miller, \& Tom E. C. Smith}

This proven resource gives practical strategies for classroom instruction from early childhood through adolescence. The new fourth edition has been revised to reflect current research within the language area, with particular emphasis on evidence-based practices for language acquisition, language arts instruction, and linguistic diversity.

The book provides effective assessment and curriculum strategies that are applicable to students across the entire range of disability, including autism spectrum disorders. It is a complete revision and includes a glossary. You will find it to be an engaging experience and much more.

\section{Special Features:}

- Thorough and concrete treatment of assessment procedures

- Hands-on, innovative classroom instruction strategies

- Presents powerful strategies to conquer language difficulties

- Emphasis on evidence-based practices

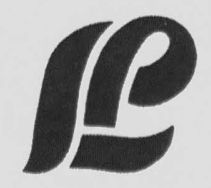

Love Publishing Company / Denver, Colorado 80222 www.lovepublishing.com / Ipc@lovepublishing.com 


\section{professional update}

Council for Exceptional Children (CEC) Annual Convention and Expo

April 3-6, 2013

San Antonio, Texas

Contact: $888-232-7733$

e-mail: service@cec.sped.org www.cec.sped.org

\section{American Education Research Association} Annual Meeting

April 27-May 1, 2013

San Francisco, California

Contact: 202-238-3200

www.aera.net

\section{American School Counselor Association Annual Conference}

June 30-July 3, 2013

Philadelphia, Pennsylvania

Contact: $\quad 800-306-4722$

e-mail: asca@schoolcounselor.org www.schoolcounselor.org

Autism Society 44th National Conference and Exposition

July $10-13,2013$

Pittsburg, Pennsylvania

Contact: e-mail: conference@autism-society.org www.autism-society.org 